\title{
3. AGE OF THE UPPER VOLCANICLASTIC DEBRIS FLOW AT SITE 747: A SPECIAL STUDY ${ }^{1}$
}

\author{
Marie-Pierre Aubry ${ }^{2}$ and W. A. Berggren ${ }^{3}$
}

\begin{abstract}
A detailed study of the Paleogene sediments recovered from Holes 747 A and 747C has been conducted in order to date precisely the volcaniclastic deposits in Cores 120-747A-20X and 120-747C-3R and to provide a biostratigraphic framework for the apparently condensed, bioturbated interval of lower Paleocene-lower Eocene chalks observed in Holes $747 \mathrm{~A}$ and $747 \mathrm{C}$. This study has been made with the aim of providing data on the reconstruction of the Late Cretaceous-early Cenozoic geotectonic history of the Northern Kerguelen Plateau. A series of closely spaced samples has been taken throughout the section. Samples were also taken from suspected burrows in order to compare their nannofossil assemblages with those of the enclosing matrix, and from intraclasts.
\end{abstract}

\section{HOLE 747A}

\section{Calcareous Nannofossils}

Results from the calcareous nannofossil biostratigraphic analysis of Hole 747A are presented in Figures 1 and 2 and Plates 1 and 2 . A detailed range chart of the calcareous nannofossil distribution throughout the section will be provided in Volume 120 of the Proceedings of the Ocean Drilling Program, Scientific Results.

Two biostratigraphic sequences can be recognized as follows:

1. A very condensed, highly bioturbated, lower Eocene to uppermost Paleocene section was recovered in Sections 120-747A19X-1 and 120-747A-19X-2. Biostratigraphic subdivision can be confidently established between Samples 120-747A-19X-1, $12 \mathrm{~cm}$, and 120-747A-19X-2, $118 \mathrm{~cm}$ (Fig. 1). As in Core 120-747C$2 \mathrm{R}-4$, an interval with hard clasts of Danian chalk with yellow patina occurs within Zone NP11. This interval extends from Core 120-747A-19X-2, 110-114 cm. Strong bioturbation and reworking of Danian chalk within Core $120-747 \mathrm{~A}-19 \mathrm{X}-2,118-150 \mathrm{~cm}$, precludes discrete biostratigraphic subdivisions. Occurrences of such taxa as Discoaster diastypus, Fasciculithus tympaniformis, and Heliolithus sp. aff. $H$. riedelii are indicative of lowermost Eocene and upper Paleocene sediments.

2. A thick Danian section extends from Section 120-747A19X-3 down to the volcaniclastic deposit. Because of bioturbation and reworking of Danian chalk in the upper Paleocene and lowermost Eocene, the contact between the Danian chalk and the upper Paleocene-lower Eocene chalk oozes cannot be precisely drawn. Mixing of early Danian and late Paleocene calcareous nannofossil species occurs down to Core 120-747A-19X, $95 \mathrm{~cm}$. It is clear, however, that the presence of late Paleocene taxa in most parts of this interval results from burrowing activities. Below Core 120-747A-19X, $95 \mathrm{~cm}$, only early Paleocene taxa were encountered. Zone NP3 is developed down to Core 120-747A-20X-2, $150 \mathrm{~cm}$. Because of bioturbation, Zone NP2 cannot be clearly delineated from Zone NP3. Reworking of Cretaceous taxa is observed in Core 120-747A-20X-2, 31-46 cm. It

\footnotetext{
${ }^{1}$ Schlich, R., Wise, S. W., Jr., et al., 1989. Proc. ODP, Init. Repts., 120: College Station, TX (Ocean Drilling Program).

2 Départment des Sciences de la Terre, Université Claude-Bernard, 15-43 Boulevard du 11 Novembre, 69622 Villeurbane, France (current address: Department of Geology and Geophysics, Woods Hole Oceanographic Institution, Quissett Campus, Woods Hole, MA 02543).

${ }^{3}$ Department of Geology and Geophysics, Woods Hole Oceanographic Institution, Quissett Campus, Woods Hole, MA 02543.
}

is not as massive as in Hole $747 \mathrm{C}$. Clasts of chalks occurring within the volcaniclastic deposit have been carefully studied. Based on their calcareous nannofossil assemblages, they are of three different origins. Some are from upper Maestrichtian chalk, others from lowermost Paleocene chalks (Zone NP1, with Biantholithus sparsus, the first exclusively Cenozoic form, present); still others are from lower Paleocene chalks belonging to Zone NP2. These findings imply that the volcaniclastic flow deposit was emplaced during the early Paleocene, and the event occurred within Zone NP2. It also implies that the lowermost Danian chalk (Zone NP1), which occurs just above the volcaniclastic deposit in Hole $747 \mathrm{C}$, was reworked. From a sedimentologic point of view, the volcaniclastic deposit might best be regarded as a subunit of Unit IIC rather than as a separate unit in itself.

A major unconformity is present between lower Paleocene (Danian) and upper Paleocene chalk oozes. The position of this unconformity is difficult to delineate in the core because of bioturbation and reworking. It represents a hiatus of at least $4 \mathrm{~m}$.y.

\section{Foraminifers}

Foraminifers in Holes 747A will be the object of an onshore study.

\section{HOLE $747 C$}

\section{Calcareous Nannofossils}

Results from the calcareous nannofossil biostratigraphic analysis are presented in Figures 3-5, and illustrations of Cores 120$747 \mathrm{C}-3 \mathrm{R}$ and $-4 \mathrm{R}$ are shown in Plates 1 and 3. Observations and main conclusions are summarized below. A detailed range chart of calcareous nannofossil distribution will be provided in Volume 120 of the Proceedings of the Ocean Drilling Program, Scientific Results.

Three stratigraphic sequences can be recognized:

1. An Oligocene and upper Eocene section extends from Core 120-747C-1R down to Core 120-747C-2R-3, $142 \mathrm{~cm}$ (150-172.92 m below seafloor [mbsf]). The section is continuous across the Eocene/Oligocene boundary, which lies at about $171.40 \mathrm{mbsf}$. A short hiatus (early Oligocene) is associated with the phosphatic interval recovered in Core $120-747 \mathrm{C}-2 \mathrm{R}-1,83-93 \mathrm{~cm}$.

2. A very condensed, yet apparently undisturbed, lower Eocene to uppermost Paleocene section was recovered from Core $120-747 \mathrm{C}-2 \mathrm{R}-3,143 \mathrm{~cm}$, to Core $120-747 \mathrm{C}-2 \mathrm{R}-5,10 \mathrm{~cm}$. Biostratigraphic subdivision of the lower Eocene part of this section could be clearly established. Preservation in this interval is 


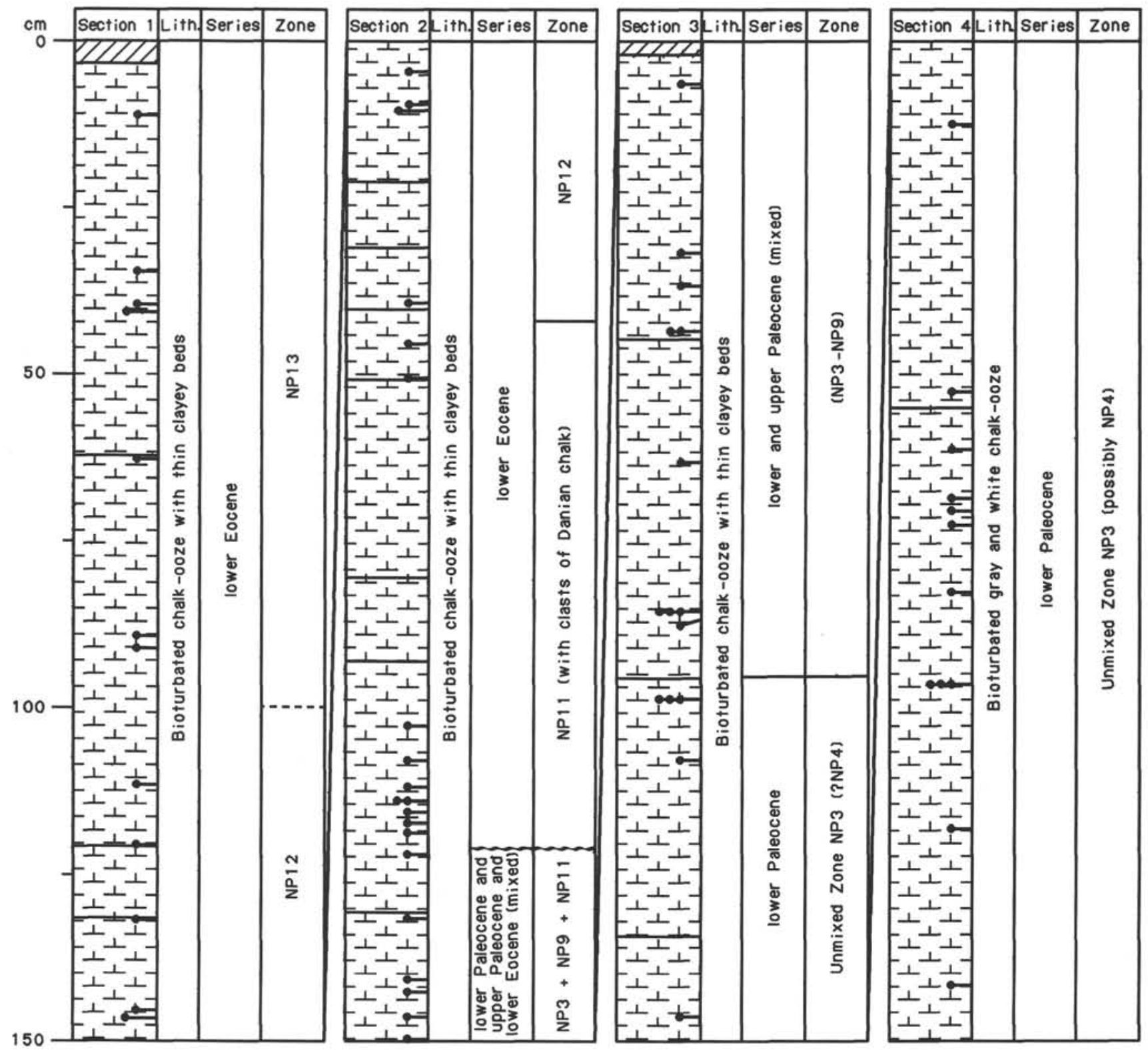

Figure 1. Calcareous nannoplankton biostratigraphy of Hole 747A (Sections 120-747A-19X-1 to 120-747A-19X-4). Locations of toothpick samples are indicated by dots.

remarkably good, an unusual fact considering the extremely low sedimentation rates. Both clear biostratigraphic resolution and excellent preservation imply that burrowing activities were rather reduced while the sediment was being deposited. This is in strong contrast with uppermost Paleocene sediments in which mixing is very intensive, thus blurring the biostratigraphic information. Indurated clasts of Danian sediments (Zones NP3-NP4 undifferentiated) occur in Core $120-747 \mathrm{C}-2 \mathrm{R}-4,132-133 \mathrm{~cm}$. The lithologic discontinuity observed at this level does not correspond with any biostratigraphic discontinuity. Soft clasts of Danian chalk occur from Core $747 \mathrm{C}-2 \mathrm{R}-4,133 \mathrm{~cm}$, to Core $747 \mathrm{C}-2 \mathrm{R}-5$, around $10 \mathrm{~cm}$. It is likely that these latter result from erosion of the Danian chalk upon initiation of deposition above the intraPaleocene unconformity.

3. A thick Danian section extends from Core 120-747C-2R-5, $10 \mathrm{~cm}$, down to the volcaniclastic deposits. Clasts of lower Danian sediments occur in the volcanic gravel. Most of this section belongs to Zone NP3 and possibly to Zone NP4 in its upper part (Ellipsolithus macellus might not occur at this latitude or might be dissolved). Assemblages are very homogeneous throughout this interval, and no differences were observed between assemblages taken from close levels showing different lithologies or representing suspected burrows and encasing matrix. Reworking of Cretaceous forms is occasional above Core 120-747C-3R-1, $62 \mathrm{~cm}$. From this level down to Core $120-747 \mathrm{C}-3 \mathrm{R}-3,14 \mathrm{~cm}$, reworking of Cretaceous species is more common, although it is still very restricted. Massive reworking of Cretaceous taxa occurs from Core $120-747 \mathrm{C}-3 \mathrm{R}-3,25 \mathrm{~cm}$, down to the contact with the volcaniclastic deposits in Core 120-747C-3R-3, $38 \mathrm{~cm}$. In this interval assigned to the earliest Paleocene (Zone NP1), Danian coccoliths are extremely diluted among Cretaceous forms, but Thoracosphaera operculata is common.

An intraclast taken in the volcaniclastic deposits in Core 120$747 \mathrm{C}-3 \mathrm{R}-3,55 \mathrm{~cm}$, yielded characteristic earliest Paleocene nannoflora, including numerous T. operculata, Markalius inversus, 

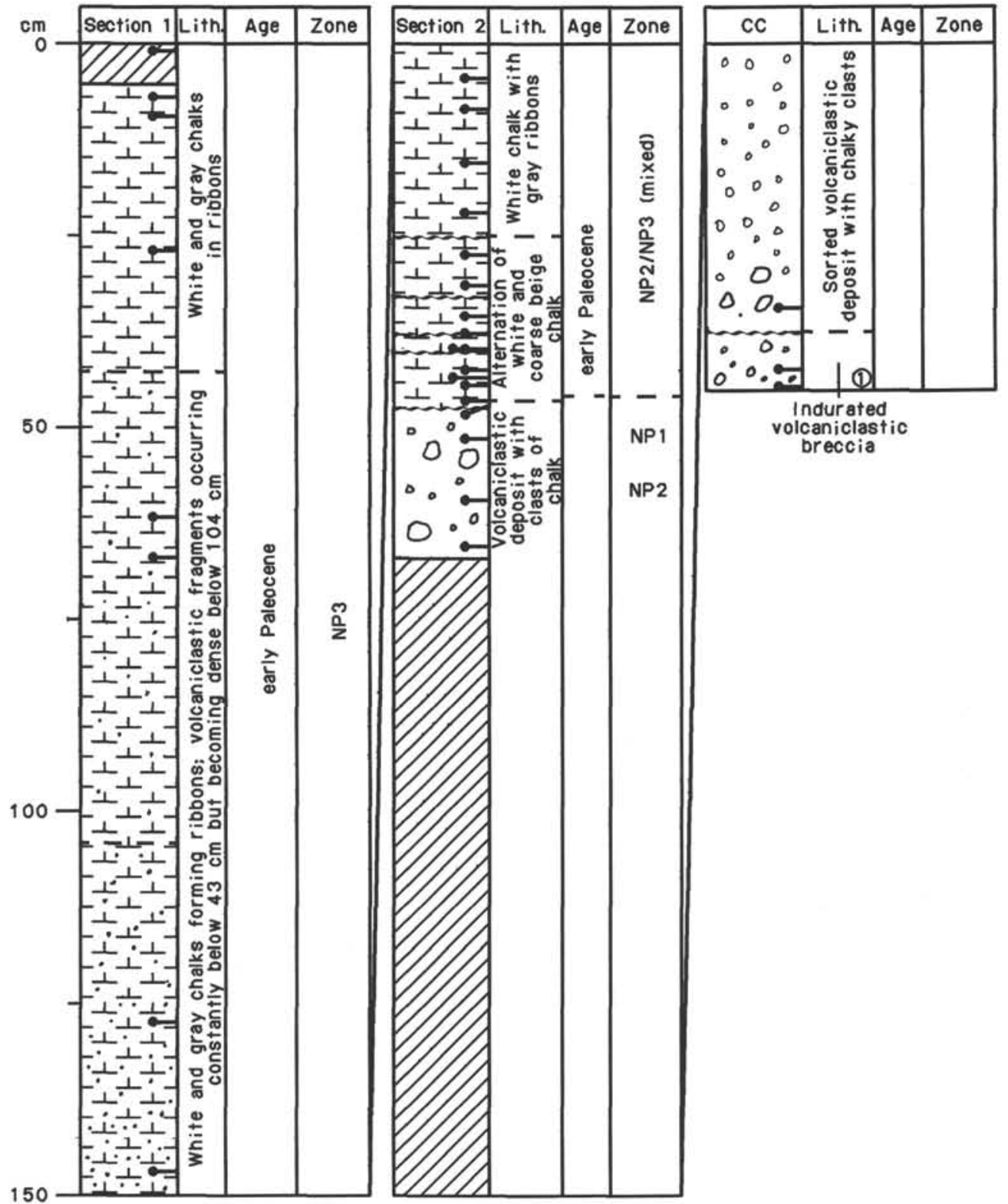

Figure 2. Calcareous nannoplankton biostratigraphy of Hole 747A (Sections 120-747A-20X-1, 120-747A$20 \mathrm{X}-2$, and 120-747A-20X-CC). Locations of toothpick samples are indicated by dots. (1) = Clast of indurated Upper Cretaceous chalk.

Placozygus sigmoides, and tiny species of the genera Biscutum and Prinsius. The presence of this intraclast as part of the gravel implies that deposition of this gravel occurred in the earliest $\mathrm{Pa}$ leocene (during Zone NP1 or close to the NP1/NP2 biozonal boundary).

Two major unconformities are present:

1. A lower Eocene (Zone NP13)/upper Eocene (Zone NP19NP20) unconformity, which represents a minimum hiatus of 15 m.y., occurs at 172.95 mbsf. This unconformity can be seen as a slight lithologic change (mainly in color).

2. An upper Paleocene (mixed Zones NP8 and NP9)/lower Paleocene (Zones NP3-NP4 undifferentiated) unconformity, which represents a hiatus of at least 4 m.y., occurs at about 174.60 mbsf. This unconformity does not seem to have a lithologic expression.

\section{Foraminifers}

A detailed, if still preliminary, study has been made of the distribution of planktonic and benthic foraminifers from Cores $120-747 \mathrm{C}-2 \mathrm{R}$ and $-3 \mathrm{R}$ in order to provide a stronger bio- and chronostratigraphic framework (complementing the separate study made on calcareous nannoplankton) as well as paleobathymetric information input in reconstructing the late Mesozoicearly Cenozoic geotectonic history of the Southern Kerguelen Plateau. A series of closely spaced samples has been taken throughout the sequence. Results of this investigation are summarized in Figures 3-7.

Three stratigraphic sequences have been recognized. (Differences in depth in core listed here and those cited in the report on calcareous nannoplankton are due to the different sampling levels and/or to different placement of zonal/chronostratigraphic boundaries by the respective fossil groups.) 

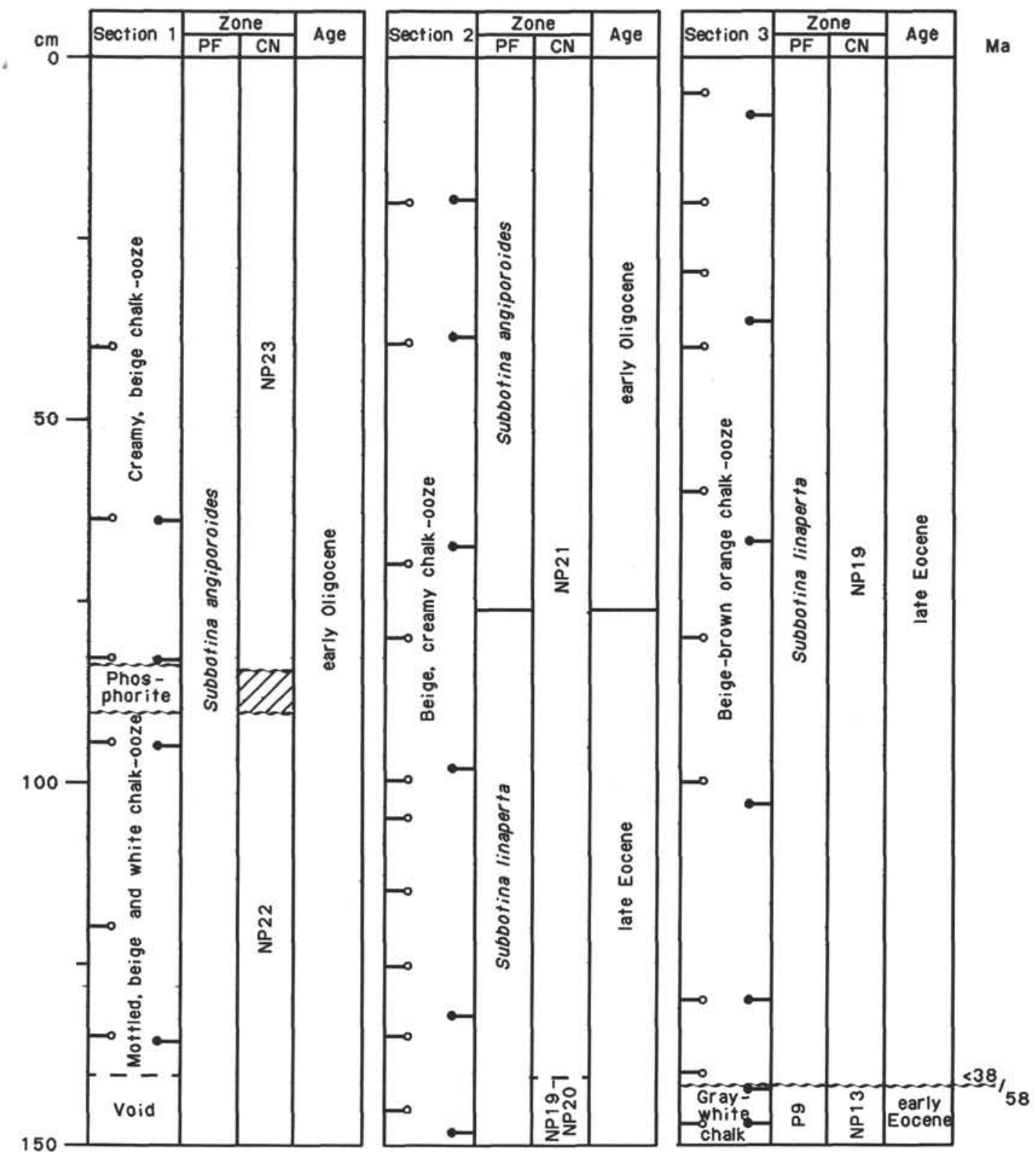

Figure 3. Calcareous plankton biostratigraphy of Hole $747 \mathrm{C}$ (Sections $120-747 \mathrm{C}-2 \mathrm{R}-1$ to $120-747 \mathrm{C}-2 \mathrm{R}-3$ ). PF = planktonic foraminifers and $\mathrm{CN}=$ calcareous nannoplankton. Locations of toothpick samples are indicated by dots; locations of foraminifer samples by open circles.

1. A lower Oligocene and upper Eocene sequence extends from Core 120-747C-1R to Core 120-747C-2R-3, $142 \mathrm{~cm}(150$ 172.92 mbsf) (Fig. 3). Only Cores $120-747 \mathrm{C}-2 \mathrm{R}$ and $-3 \mathrm{R}$ have been examined in (varying) detail for this report. The Eocene/ Oligocene boundary is placed between Samples 120-747C-2R-2, $70 \mathrm{~cm}$, and $120-747 \mathrm{C}-2 \mathrm{R}-2,80 \mathrm{~cm}$, based on the last (LAD) occurrence of Globigerapsis index and Subbotina linaperta.

2. A strongly condensed, visibly bioturbated, lower Eocene to uppermost Paleocene sequence extends from Samples 120$747 \mathrm{C}-2 \mathrm{R}-3,142 \mathrm{~cm}$, to $120-747 \mathrm{C}-2 \mathrm{R}-5$, around $7 \mathrm{~cm}$ (Fig. 4). Although the evidence for downward displacement of faunal elements is seen, a normal sequential development of lower Eocene planktonic foraminifer Zones P6a-P9 occurs. Burrowing is most intense in the uppermost Paleocene-basal Eocene (lower part of Section 120-747C-2R-4 and top of Section 120-747C2R-5).
The stratigraphic distribution of planktonic and benthic foraminifers in the upper part of Core $747 \mathrm{C}-2 \mathrm{R}-5$ and lower part of Core $747 C-2 R-4$ is shown in Figure 4 . In undisturbed stratigraphic sequences, there is a major taxonomic turnover at the Paleocene/Eocene boundary (Zones P6a/P6b; Tjalsma and Lohmann, 1983). In Sample 120-747C-2R-4, $140 \mathrm{~cm}$, several typical Paleocene benthic foraminifers have their highest occurrence (LAD) associated with a typical P6a fauna (Morozovella subbotinae and $M$. marginodentata, among others). Associated with these forms are several typically Eocene forms that normally appear sequentially in Zones $\mathrm{P} 6 \mathrm{~b}, \mathrm{P} 7$, and P8, attesting to the influence of burrowing in this interval. At the same time, several benthic forms, typically restricted to the Paleocene (i.e., Stensioina beccariiformis, Neoeponides hillebrandti, Nuttallinella florealis, Anomalinoides danica, Bolivinoides delicatulus), extend up to Sample 120-747C-2R-4, 130-132 cm, which is placed 


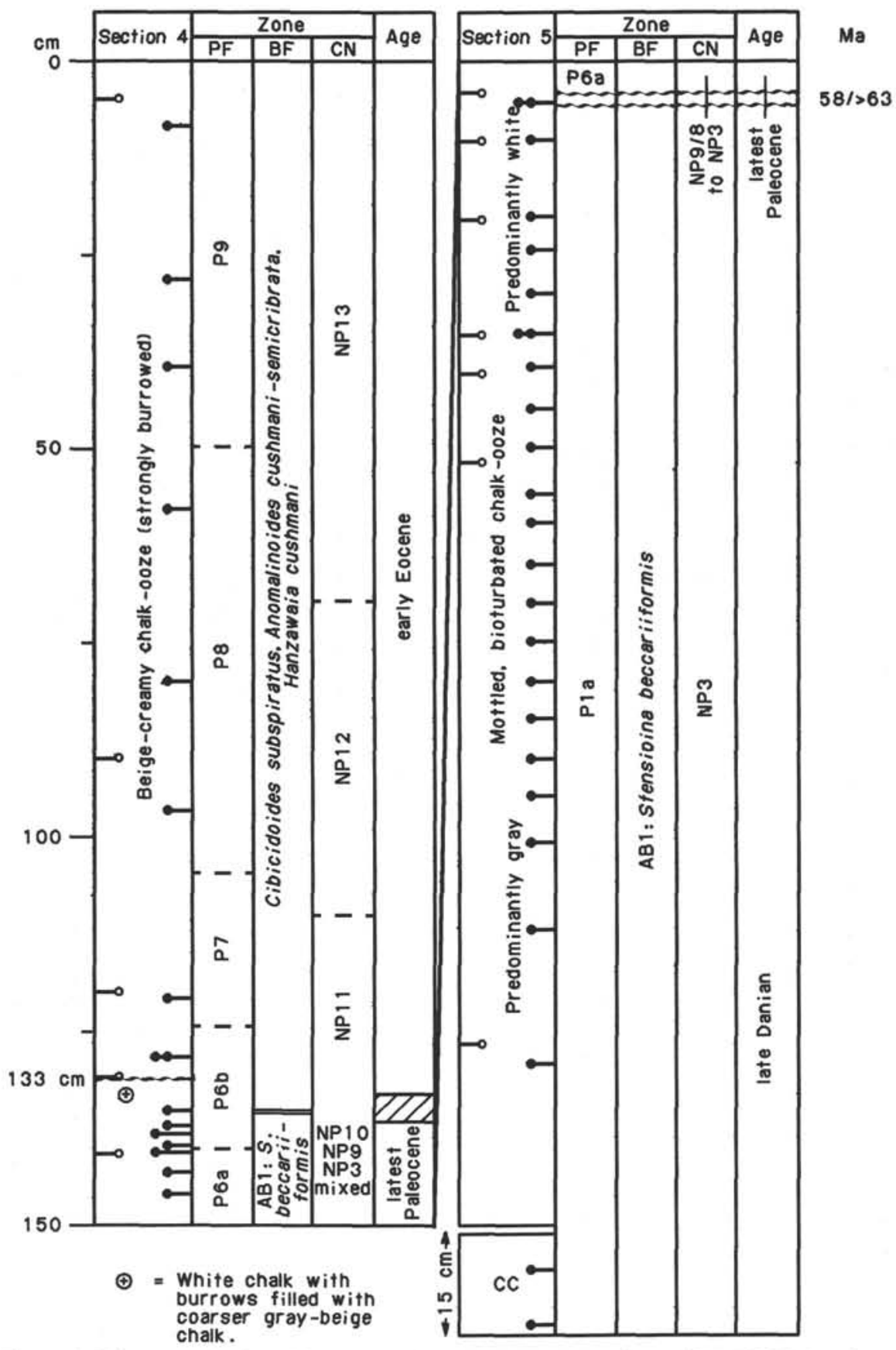

Figure 4. Calcareous plankton biostratigraphy of Hole $747 \mathrm{C}$ (Sections $120-747 \mathrm{C}-2 \mathrm{R}-4$ and $120-747 \mathrm{C}-2 \mathrm{R}-5$ ). $\mathrm{PF}=$ planktonic foraminifers, $\mathrm{BF}=$ benthic foraminifers, and $\mathrm{CN}=\mathrm{cal}-$ careous nannofossils. Locations of toothpick samples are indicated by dots; locations of foraminifer samples by open circles.

in Zone P6b based on the FAD of Morozovella lensiformis and Subbotina patagonica at the same level.

It is difficult to determine whether the overlap of several $\mathrm{Pa}$ leocene benthic taxa (which normally became extinct within Zone P6a) and Eocene forms that normally originate within the Zone P6b-P8 interval is real, or whether the juxtaposition of these two faunas is due to reworking upward and/or downward by burrowing, which is evident upon visual inspection of the stratigraphic interval in question. It is essentially a moot point inasmuch as there is a normal succession of latest Paleoceneearly Eocene zonal marker forms in this interval that allows recognition of Zones P6a, P6b, and P7. Upper Danian planktonic foraminifers occur as a minor component of the uppermost $\mathrm{Pa}$ leocene (P6a) assemblage of Sample 120-747C-2R-4, 141-144 cm; in Sample 120-747C-2R-4, 130-132 cm, Danian forms are present but very rare. The presence of Danian forms in the upper Paleocene-basal Eocene of Sample 120-747C-2R-4 is attributed to reworking, following the initiation of deposition above the intraPaleocene unconformity near the top of Section 120-747C-2R-3. Thus, we would ascribe the presence of late Danian planktonic foraminifers and the extension of several (restricted to) Paleocene deep-water benthic taxa into the uppermost Paleocene and basal Eocene of Hole 747C as more likely due to reworking than to other causes. 


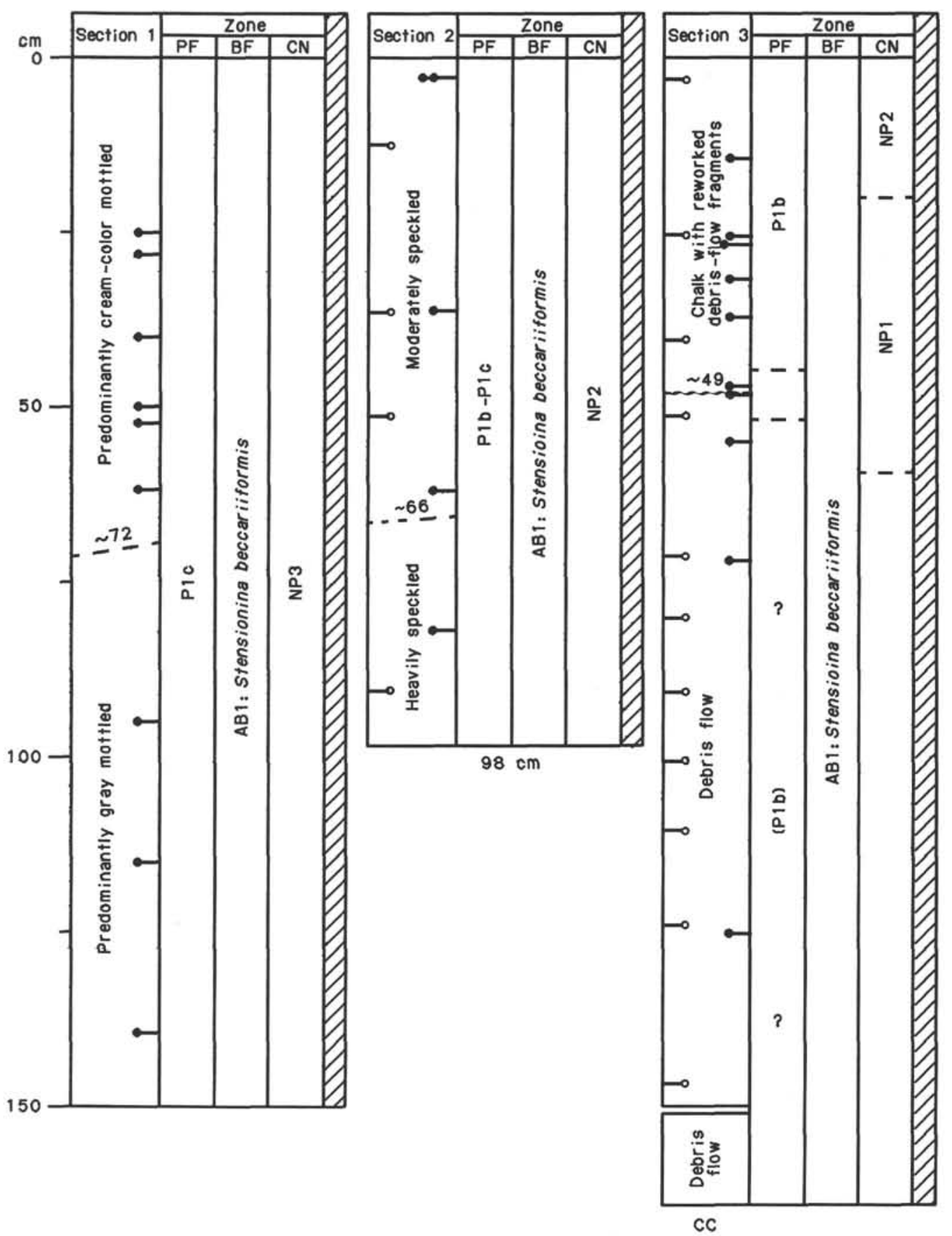

Figure 5. Calcareous nannoplankton biostratigraphy of Hole 747C (Sections 120-747C-3R-1 to 120-747C-3R-3). $\mathrm{PF}=$ planktonic foraminifers, $\mathrm{BF}=$ benthic foraminifers, and $\mathrm{CN}=$ calcareous nannofossils. Locations of toothpick samples are indicated by dots; locations of foraminifer samples by open circles.

3. A thick (around 4-5 m) Danian sequence extends from Sections $120-747 \mathrm{C}-2 \mathrm{R}-5$, around $7 \mathrm{~cm}$, to $120-747 \mathrm{C}-3 \mathrm{R}-3$, around $48 \mathrm{~cm}$, at which level there is a volcaniclastic (debris-flow) deposit that extends from Section 120-747C-3R-3, around $48 \mathrm{~cm}$, to the bottom of Section 120-747C-3R-3 and the core catcher (around $125 \mathrm{~cm}$ ) (Fig. 5). The upper Danian (P1c) is separated from the uppermost Paleocene (P6a) by an unconformity located between Samples 120-747C-2R-5, 3-5 cm, and 120-747C$2 \mathrm{R}-5,7-11 \mathrm{~cm}$ (Figs. 4 and 5). The younger Danian fauna was observed in Sample 120-747C-2R-5, 9-11 cm, and contains, in addition to a diverse P1c planktonic fauna and a typical deepwater Paleocene benthic assemblage, a diverse downward dis- placed (bioturbated) early Eocene assemblage (Subbotina frontosa, Acarinina angulosa, Acarinina soldadoensis, Acarinina coalingensis, and Acarinina primitiva, among others). Most of the Danian interval (Sections 120-747C-2R-5 and 120-747C-3R1) belongs to the upper Danian (Zone P1c); Section 120-747C3R-2 belongs to Zones P1b-P1c; and Sample 120-747C-3R-3, 0$48 \mathrm{~cm}$, to Zone Plb (Figs. 4 and 5). Diverse and well-preserved Danian faunas characterize this interval. Typical Paleocene deep-water benthic foraminifers belonging to Zone $\mathrm{AB1}=$ Stensioina beccariiformis Zone (Berggren and Miller, in press) occur throughout the Danian interval and to the top of the $\mathrm{Pa}$ leocene near the top of Section 120-747C-2R-5 (see Figs. 4 and 


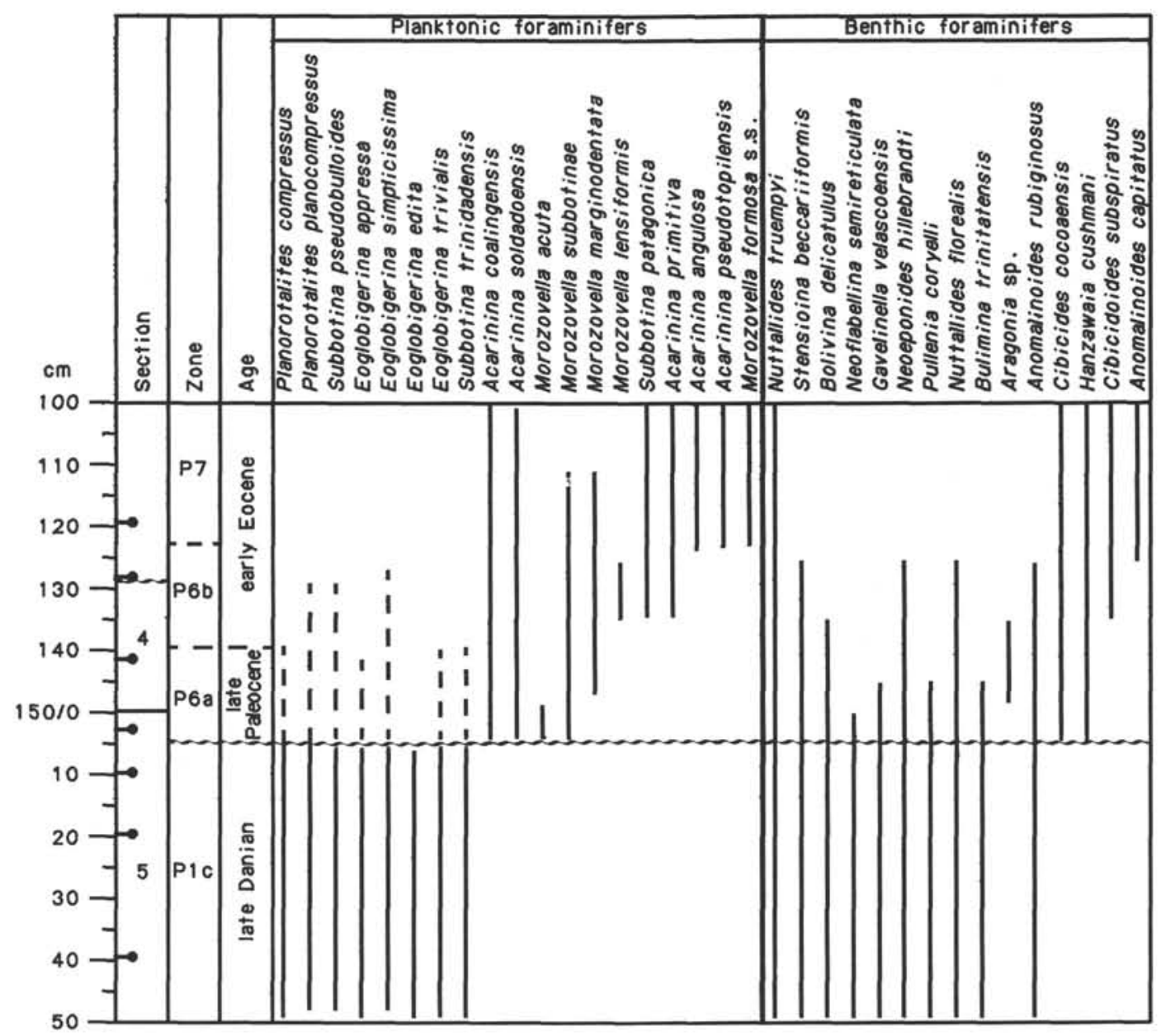

Figure 6. Stratigraphic distribution of foraminifers in Hole 747C (lower part of Section 120-747C-2R-4 and upper part of Section 120-747C-2R-5).

5) with several forms extending into the basal Eocene. The volcaniclastic debris flow extends from Interval 120-747C-3R-3, around $48 \mathrm{~cm}$, to $120-747 \mathrm{C}-3 \mathrm{R}-3,150 \mathrm{~cm}$, plus the core catcher (around $23 \mathrm{~cm}$ ) or a total thickness of about $125 \mathrm{~cm}$ (Fig. 7). Reworking of volcaniclastic fragments into the cream-colored chalk above is clearly seen. It is most intense in the upper $48 \mathrm{~cm}$ of Section 120-747C-3R-3, less intense in the lower approximate $30 \mathrm{~cm}$ of Section 120-747C-3R-2, and becomes faint in the upper approximate $65 \mathrm{~cm}$ of Section 120-747C-3R-2 (Fig. 7).

A detailed examination of Section $120-747$ C-3R-3 has been made in order to determine the nature and biostratigraphy of the volcaniclastic debris flow and the normal pelagic sediments immediately above. Several observations are pertinent in this context.

1. Chalk ooze clasts occur within the volcaniclastic gravels. Examination of an intraclast within the debris flow at Interval 120-747C-3R, $55 \mathrm{~cm}$, yielded a Zone P1b (early-middle Danian) planktonic foraminifer fauna as well as elements of the deep-water (about $2 \mathrm{~km}$ ) Paleocene $S$. beccariiformis assemblage (Tjalsma and Lohmann, 1983).

2. The volcaniclastic debris flow contains a diverse middle to upper Maestrichtian planktonic foraminifer fauna (globotruncanids, rugoglobigerinids, globotruncanellids, heterohelicids, and globigerinelloidids, among others). Associated with them are rare Upper Cretaceous benthic foraminifers.
3. Elements of the Paleocene deep-water benthic foraminifer assemblage (Stensioina beccariiformis, Nuttallides truempyi, Gavelinella velascoensis) occur throughout the volcaniclastic debris flow to the base of Section 120-747C-3R-3. Additional elements (Bolivinoides delicatulus and Coryphostoma midwayensis) have been found as low as Core 120-747C-3R-3, $110 \mathrm{~cm}$ (in the middle of the debris flow).

4. Definite Danian planktonic foraminifer assemblages have not been identified within the "matrix" of the debris flow. They have been identified however, from intraclasts within the debris flow (see above). Their absence in the volcaniclastic debris flow is due, no doubt, to dilution by rapid deposition of the debris flow itself.

5. Immediately above the debris flow (above Core $120-747 \mathrm{C}$ $3 R-3$, around $48 \mathrm{~cm}$ ) in the cream-colored pelagic chalks with abundant fragments of the debris flow, the Danian planktonic and benthic foraminifer fauna develops (diversifies) rapidly at the expense of the (reworked) Maestrichtian (predominantly) planktonic foraminifer fauna.

The sequence of events is shown schematically (and not to scale) in Figure 7.

One further point deserves mentioning here. Semiquantitative estimates of the relative abundance of the Paleocene deepwater benthic foraminifer assemblages present in Core 120$747 \mathrm{C}-3 \mathrm{R}$ indicate that $S$. beccariiformis and $N$. truempyi occur in an approximate ratio of $2: 1$. This, plus the sporadic occur- 


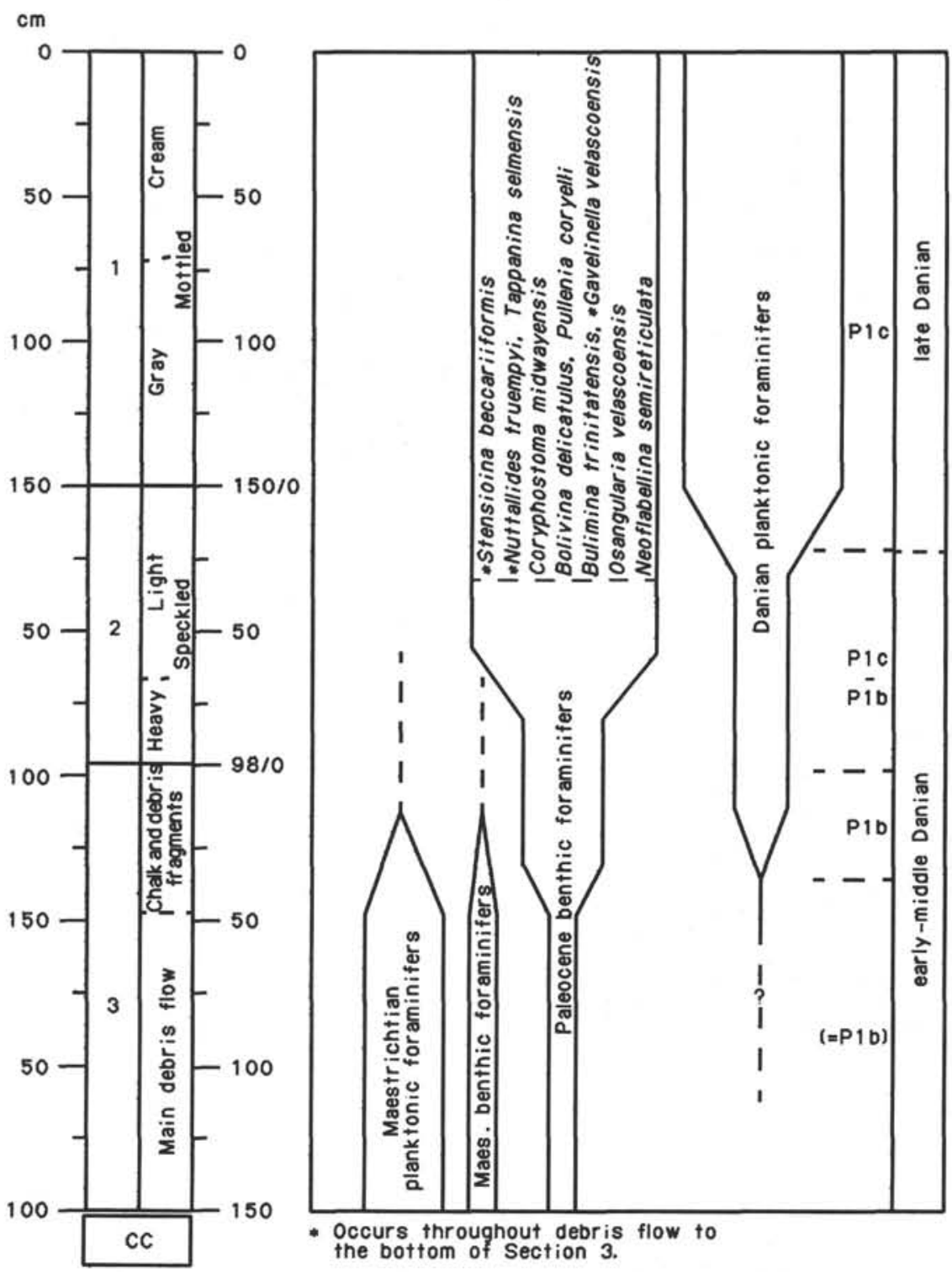

Figure 7. Schematic distribution of foraminifers in Hole 747C (Sections 120-747C-3R-1 to 120 747C-3R-3).

rence of Aragonia, would suggest that Danian chalk-ooze at Site 747 was deposited at a depth closer to $2 \mathrm{~km}$ than $1 \mathrm{~km}$ (Tjalsma and Lohmann, 1983; Van Morkhoven et al., 1986).

\section{SEDIMENTATION RATES}

A sedimentation rate of $0.78 \mathrm{~m} / \mathrm{m}$.y. can be tentatively proposed for the lower Eocene-upper Paleocene section in Hole 747A, based on the FAD of Discoaster lodoensis and the LAD of Tribrachiatus orthostylus. A rate of $8 \mathrm{~m} / \mathrm{m}$.y. is tentatively proposed for the lower Paleocene chalk oozes.

These rates are higher than those estimated for the same intervals in Hole $747 \mathrm{C}$. It is probable that bioturbation and reworking in the lower Eocene-upper Paleocene interval and in the lower Danian in Hole $747 \mathrm{~A}$ explain the discrepancies. It should also be considered that for rates less than $1.0 \mathrm{~m} / \mathrm{m} . \mathrm{y}$., any uncertainty on the datum levels used to estimate the rates of sedimentation will have considerable effect on the estimate. The rate estimated here for the Danian chalk is probably more reliable that the estimate suggested for the same interval in Hole
$747 \mathrm{C}$. Onshore refinement of the biostratigraphic subdivisions will allow better resolution.

Sedimentation rates in Hole $747 \mathrm{C}$ varied greatly during the Paleogene, as follows:

1. About $1.57 \mathrm{~m} / \mathrm{m} . \mathrm{y}$. during the early Danian (Zone NP2) (but see discussion below).

2. Between $1.73 \mathrm{~m} / \mathrm{m} . \mathrm{y}$. and $4.87 \mathrm{~m} / \mathrm{m} . \mathrm{y}$. during the late Danian. The first estimate corresponds to a conservative figure, based on the assumption that Zone NP4 is represented in the section and thus is a minimal rate. The second estimate is based on the assumption that Zone NP3 alone is represented, but in its full extent. However, it cannot be excluded that the Danian is truncated at the top.

3. About $0.25 \mathrm{~m} / \mathrm{m}$.y. during the early Eocene.

4. Over $1.4 \mathrm{~m} / \mathrm{m} . \mathrm{y}$. during the late Eocene and $1.1 \mathrm{~m} / \mathrm{m} . \mathrm{y}$. during the early Oligocene. These estimates are minimal because the upper Eocene and lower Oligocene sequences are truncated. 
Further shore-based studies will allow refinement of these estimates.

\section{CORRELATION BETWEEN HOLES 747A AND 747C}

Figures 8 and 9 show correlations between Cores 120-747A-19X and $-20 \mathrm{X}$ of Hole $747 \mathrm{~A}$ and Cores $120-747 \mathrm{C}-2 \mathrm{R}$ and $-3 \mathrm{R}$ of Hole $747 \mathrm{C}$.

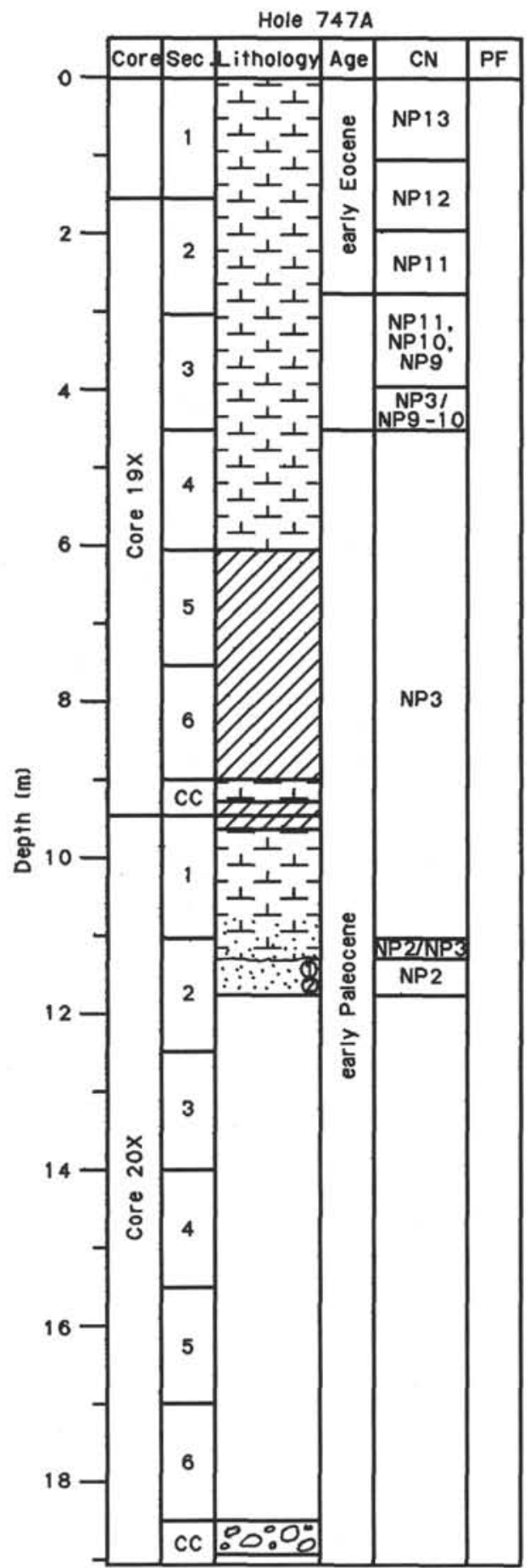

Three stratigraphic sequences were recognized in Hole 747C; only two were recovered in Hole 747A. Poor recovery in Hole 747A explains why the lower Oligocene-upper Eocene sequence of Hole $747 \mathrm{C}$ was not recovered in Hole 747A (Fig. 9). The lower Eocene-upper Paleocene sequence is somewhat more developed in Hole 747A than it is in Hole 747C, suggesting more truncation of the sequence in the latter hole.

Hole $747 \mathrm{C}$

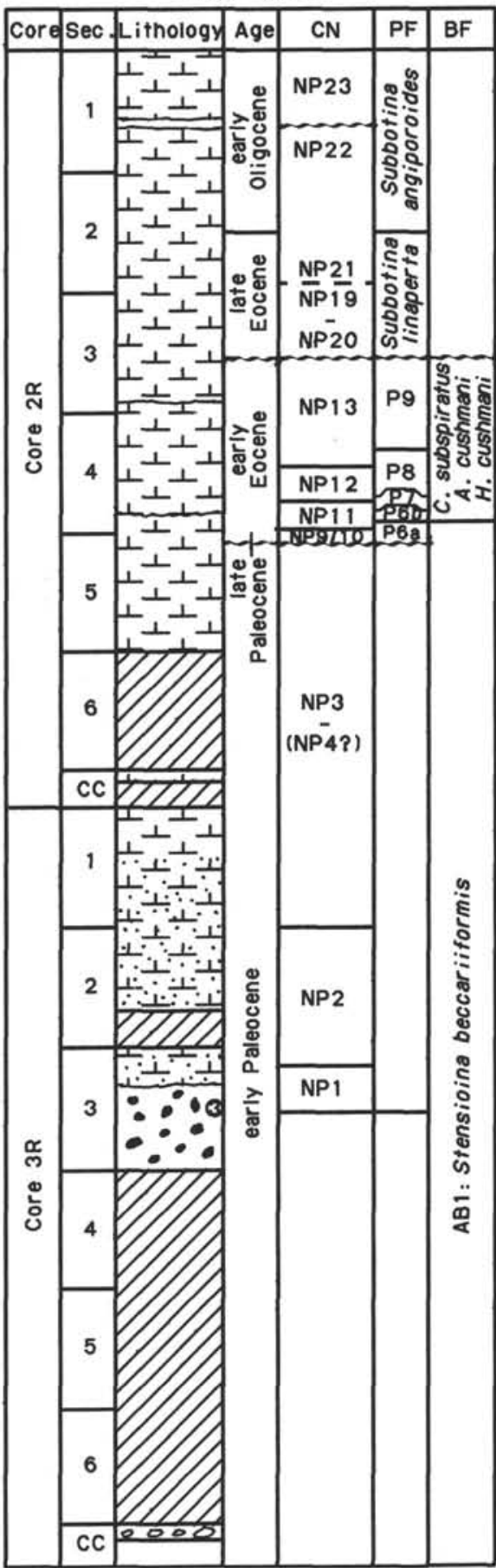

$\Phi$ = Clast of lower Paleocene chalk (Zone NP2).

(2) = Clast of lowermost Paleocene chalk (Zone NP1) with B. sparsus.

- Clast of lowermost Paleocene chalk (NP1).

Figure 8. Biostratigraphic correlation of Holes 747A (Cores 120-747A-19X and 120-747A-20X) and 747C (Cores 120-747C-2R and $-3 \mathrm{R}$ ). $\mathrm{CN}=$ calcareous nannoplankton, $\mathrm{PF}=$ planktonic foraminifers, and $\mathrm{BF}=$ benthic foraminifers. 


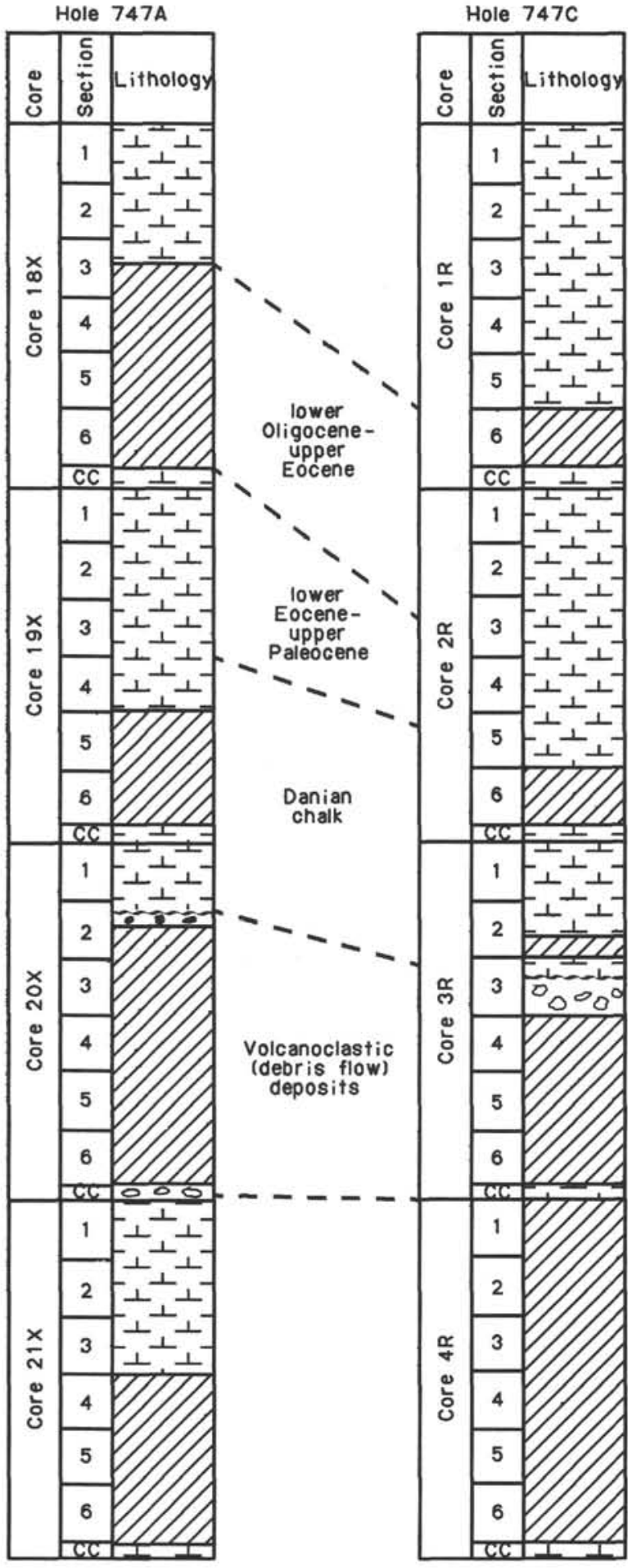

Figure 9. Lithostratigraphic correlation of Holes 747A (Cores 120$747 \mathrm{~A}-18 \mathrm{X}$ to $120-747 \mathrm{~A}-21 \mathrm{X}$ ) and $747 \mathrm{C}$ (Cores $120-747 \mathrm{C}-1 \mathrm{R}$ to $-4 \mathrm{R}$ ).
The lower Eocene-upper Paleocene sequence is much more strongly bioturbated in the former hole than in the latter.

The Danian section is as well developed in both holes.

\section{CONCLUSIONS}

We are able to draw the following conclusions for Holes $747 \mathrm{~A}$ and $747 \mathrm{C}$, based on our observations in the above discussion:

1. The volcaniclastic debris flow was an almost instantaneous early Danian event that transported an early late Maestrichtian fauna into a deep-water (around $2 \mathrm{~km}$ ) early Danian pelagic environment, preserving elements of the bottom-dwelling benthic fauna, but obscuring (by dilution) the indigenous planktonic fauna.

2. An approximately 4-m.y. hiatus separates upper Danian and uppermost Paleocene sediments in Core 120-747C-2R-5, around $7 \mathrm{~cm}$, at about 175 mbsf (Fig. 4).

3. An approximately $15-16-$ m.y. hiatus separates the upper lower Eocene (Zone P9) from the upper Eocene (Subbotina linaperta Zone) in Core $120-747 \mathrm{C}-2 \mathrm{R}-3,143 \mathrm{~cm}$, which is at about 173 mbsf (Fig. 3).

4. A condensed, but essentially complete, lower Eocene biostratigraphic sequence of Zones P6-P9 occurs in Section 120$747 \mathrm{C}-2 \mathrm{R}-4$ up to the base of Section $120-747 \mathrm{C}-2 \mathrm{R}-3$ through a burrowed interval of over $150 \mathrm{~cm}$ (Figs. 3-5).

5. Site 747 appears to have subsided from outer neritic-upper bathyal depths $(<500 \mathrm{~m})$ to lower bathyal-abyssal depths (around $2 \mathrm{~km}$ ) during the short interval (around 2-3 m.y.) represented by a middle-late Maestrichtian to early Danian hiatus located between Cores 120-747C-3R and -4R.

6. The hiatus between the upper Maestrichtian chalks (Nephrolithus frequens Zone) and the lower Danian chalks (Zone P1b: Subbotina pseudobulloides Zone) represents an interval of about 2-3 m.y., the duration of which is determined by cross correlation of biostratigraphic events observed at Site 747 with those observed at Site 516 (Rio Grande Rise, South Atlantic) and the Geomagnetic Polarity Time Scale (see Berggren et al., 1983, 1985a, 1985b, 1985c).

\section{REFERENCES}

Berggren, W. A., Hamilton, N., Johnson, D. A., Pujol, C., Weis, W., Cepek, P., and Gombos, A. M., Jr., 1983. Magnetobiostratigraphy of Deep Sea Drilling Project Leg 72, Sites 515-518, Rio Grande Rise (South Atlantic). In Barker, P. F., Carlson, R. L., Johnson, D. A., et al., Init. Repts. DSDP, 72: Washington (U.S. Govt. Printing Office), 675-713.

Berggren, W. A, Kent, D. V., and Flynn, J. J., 1985a. Jurassic to Paleogene: Part 2, Paleogene geochronology and chronostratigraphy. In Snelling, N. J. (Ed.), The Chronology of the Geological Record, Geol. Soc. Mem. (London), 10:141-195.

Berggren, W. A., Kent, D. V., Flynn, J. J., and Van Couvering, J. A., 1985b. Cenozoic geochronology. Geol. Soc. Am. Bull., 96:14071418.

Berggren, W. A., Kent, D. V., and Van Couvering, J. A., 1985c. The Neogene: Part 2, Neogene geochronology and chronostratigraphy. In Snelling, N. J. (Ed.), The Chronology of the Geological Record, Geol. Soc. Mem. (London), 10:211-260.

Berggren, W. A., and Miller, K. G., 1988. Paleogene tropical planktonic foraminiferal biostratigraphy and magnetochronology. Micropaleontology, 34:362-380.

in press. Cenozoic bathyal and abyssal calcareous benthic foraminiferal zonation. Micropaleontology.

Tjalsma, R. C., and Lohmann, G. P., 1983. Paleocene-Eocene bathyal and abyssal benthic foraminifera from the Atlantic Ocean. Micropaleontology, Spec. Publ., 4:1-90.

Van Morkhoven, F.P.C.M., Berggren, W. A., and Edwards, A. S., 1986 Cenozoic cosmopolitan deep-water benthic foraminifera. Bull. Cent. Rech. Explor. Prod. Elf-Aquitaine Mem., No. 11. 


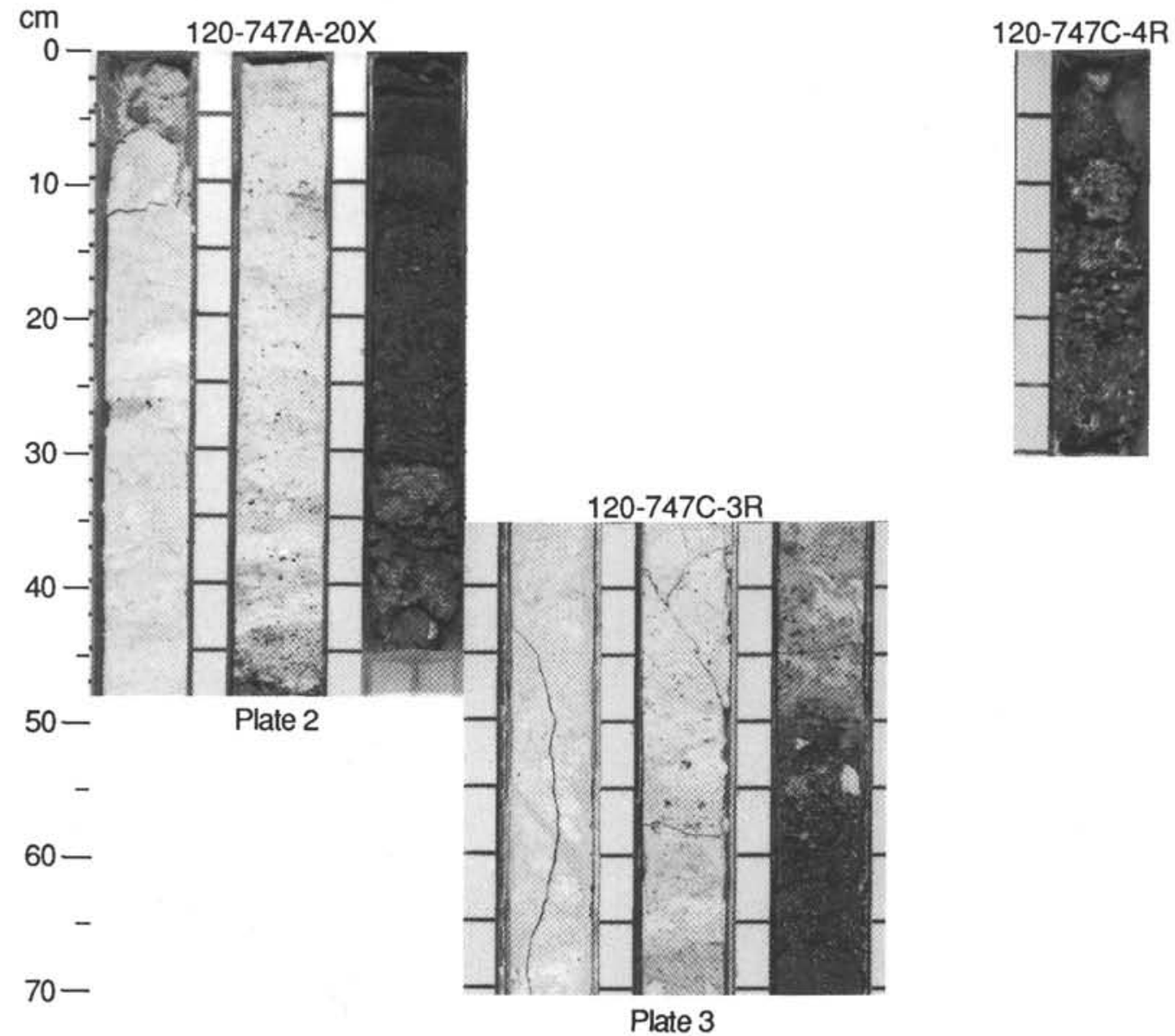

Plate 1. Cores 120-747A-20X (columns 1-3), 120-747C-3R (columns 4-7), and 120-747C-4R (column 8). Column 1 shows Section 101-747A-20X-1; column 2 shows Section 120-747A-20X-2; column 3 shows Section 120-747A-20X-CC. Columns 4-7 show Sections 120-747C-3R-1 through 120-747C3R-3 and 120-747C-3R-CC, respectively. Column 8 shows Section 120-747C-4R-CC. 


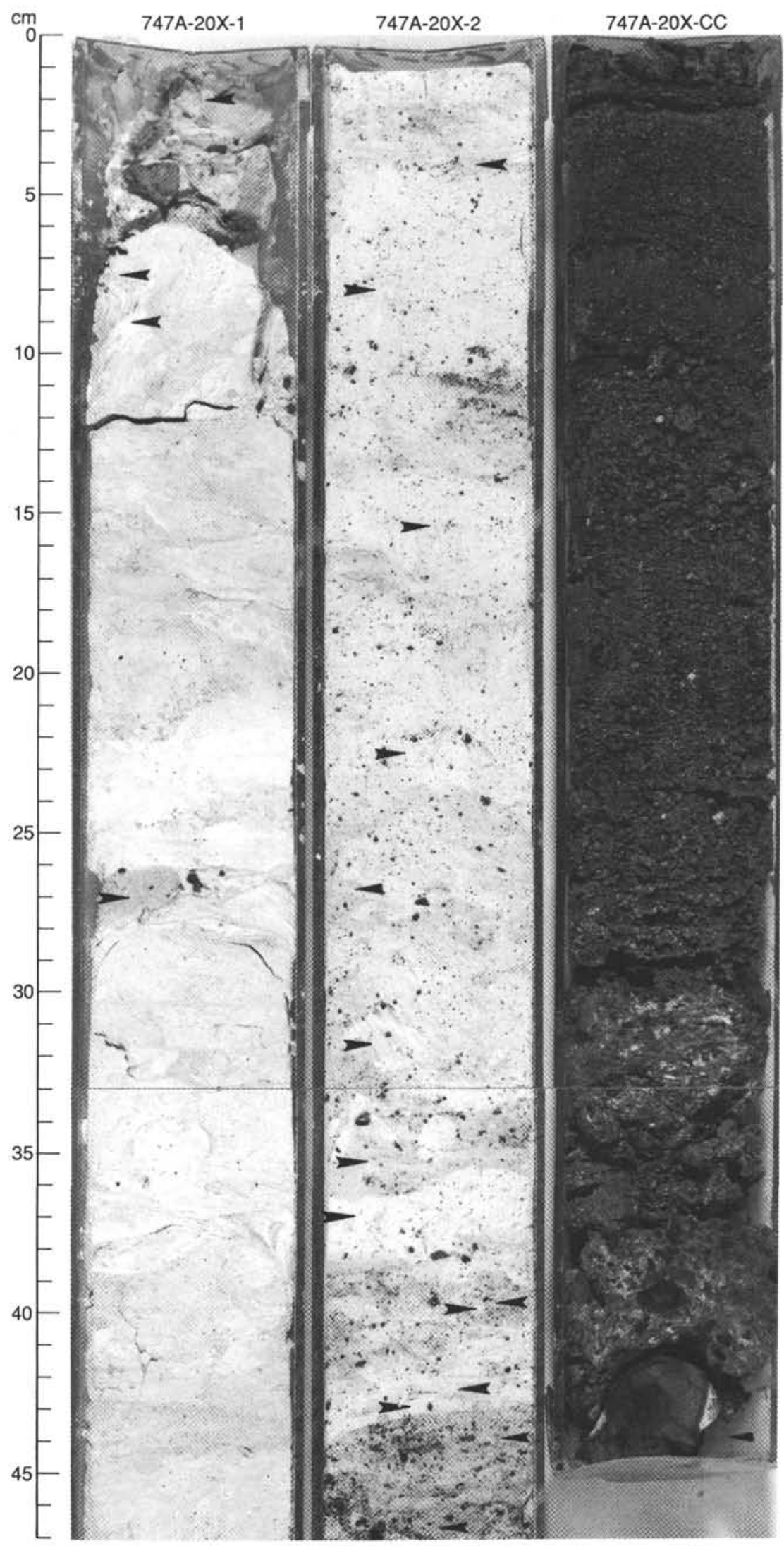

Plate 2. Details of the upper $33 \mathrm{~cm}$ and the middle part of columns 1-3 in Plate 1. Note the upward mixing of volcaniclastic sediment in the lower Danian chalk (column 2) over Interval 120-747A-20X-2, 0-33 cm. The main boundary between the upper volcaniclastic debris flow is seen in Core 120-747A-20X-2, $47 \mathrm{~cm}$ (column 2 of Plate 1). Note the upward mixing of volcaniclastic debris in lower Danian chalk over Interval 120-747A-20X-2, $33-47 \mathrm{~cm}$. 


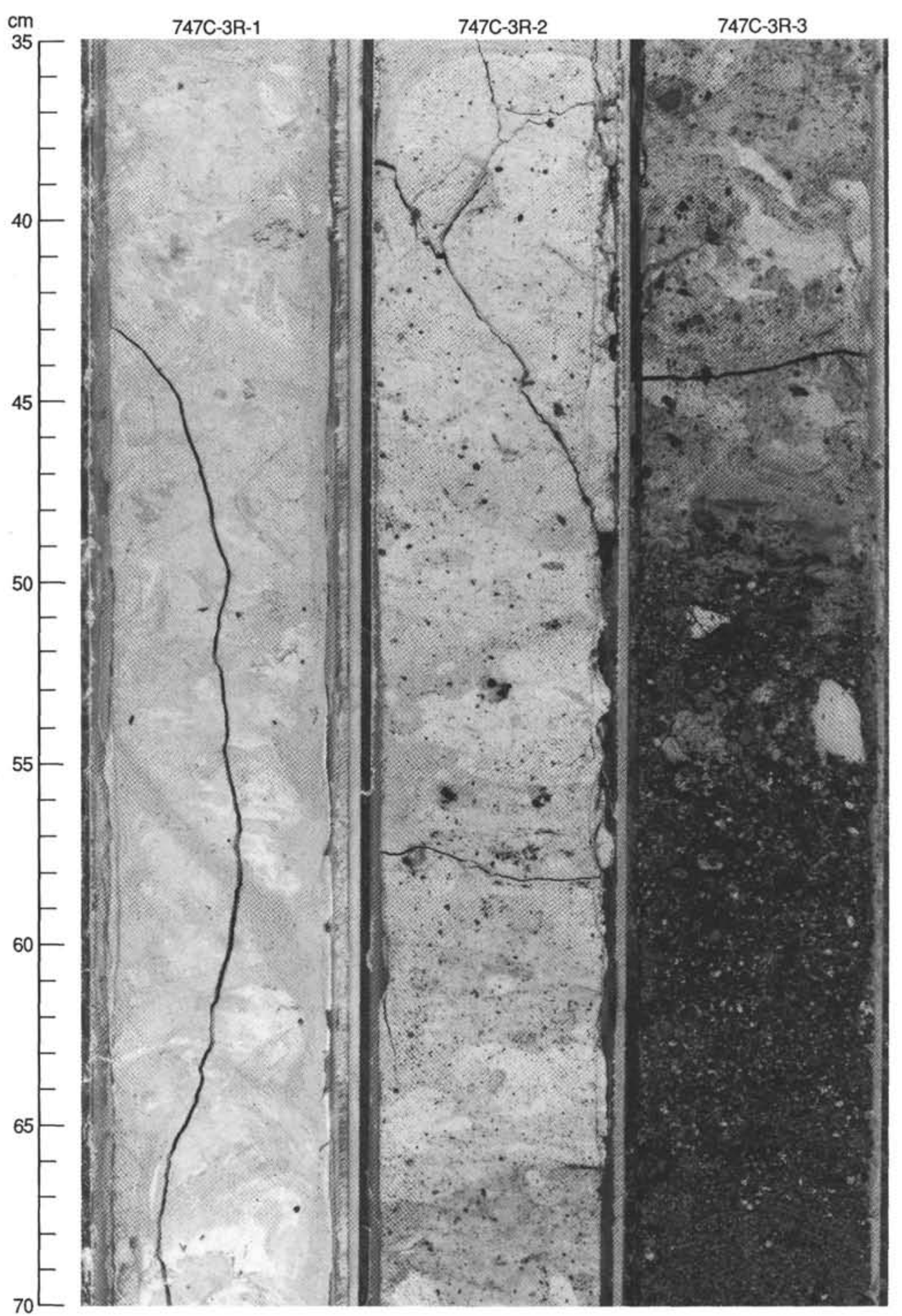

Plate 3. Detail of the middle part of columns 4-6 in Plate 1 (35-70 cm from the top of each section). The volcaniclastic intraclast with early Danian calcareous nannoflora discussed in the text is seen at $55 \mathrm{~cm}$ on the right side of the core (column 3) in Core 120-747C-3R (see also Plate 1, column 6). 